\title{
Synthesis of Sphene-pink Pigment under Various Firing Conditions
}

\author{
Hyun-Soo Lee ${ }^{\dagger}$ Joo-Seok Park*, and Byung-Ha Lee \\ Department of Materials Science \& Engineering, Myongji University, Yongin 449-728, Korea \\ *Korea Institute of Ceramic Engineering \& Technology, Seoul 153-801, Korea
}

(Received June 10, 2009; Revised August 17, 27, 2009; Accepted August 28, 2009)

\begin{abstract}
The present research was performed to determine the optimal firing condition and holding time for malayaite crystal, which is responsible for the stable pink-red coloration in glaze at high temperatures, using $\mathrm{CrCl}_{3}$ as chromophore for the synthesis of $\mathrm{Cr}_{2} \mathrm{O}_{3}-\mathrm{SnO}_{2}-\mathrm{CaO}-\mathrm{SiO}_{2}$ system pigments. The malayaite crystal was influenced by the raw materials used for synthesis, firing temperature, and holding time. Thus there are differences in the crystal phase and in the coloration according to the condition of synthesis. When $\mathrm{CrCl}_{3}$ was used as chromophore, the pigment could be synthesized at lower temperatures, because $\mathrm{CrCl}_{3}$ melts at $1150^{\circ} \mathrm{C}$, which is much lower than the temperature at which $\mathrm{Cr}_{2} \mathrm{O}_{3}$ melts (higher than $2435^{\circ} \mathrm{C}$ ). And the employed Cr ion showed a change in oxidation state. When a mineralizer was used to improve the employment of malayaite and the $\mathrm{Cr}$ ion, and the low temperature was maintained at which the malayaite crystal is produced, the production of malayaite crystal was promoted and the employment of chromophore was also promoted in the oxidation state of $\mathrm{Cr}$ (IV). The results of the experiment showed that the optimal firing condition was $18 \mathrm{~h}$ of holding time at $800^{\circ} \mathrm{C}$, using $\mathrm{CrCl}_{3}$ as chromophore, followed by $2 \mathrm{~h}$ at the raised temperature of $1150^{\circ} \mathrm{C}$. The change in coloration of the $\mathrm{Cr}$ (IV) employed by malayaite showed a very rich color of red. Thus it was possible to effectively synthesize sphene-pink pigments with more red tint at a low temperature.
\end{abstract}

Key words : Malayaite, Sphene, $\mathrm{CrCl}_{3}$, Pink, Pigment

\section{Introduction}

$\mathbf{F}$ or a long time many attempts were made to achieve red coloration in ceramic glaze, but obtaining pure red coloration was not possible. Therefore colors like pink, purple, brick red, and maroon were usually accepted as the coloration of red type colors. ${ }^{1)}$ Accordingly, it is necessary to develop red type pigments for glaze that show stable coloration at a high temperature. When $\mathrm{Cr}_{2} \mathrm{O}_{3}$ is used as chromophore, colors like pink, red, or green appear. ${ }^{2)}$ If $\mathrm{Cr}_{2} \mathrm{O}_{3}$ is used together with $\mathrm{SnO}_{2}$ and $\mathrm{CaO}$ in the glaze, the coloration becomes deep purple, which is mainly due to malayaite. Such a crystal lattice, known also as sphene, involves the binding of metal ions as chromophore such as transition metal ions. ${ }^{3)}$ In this case, it is known that the substitution of the $\mathrm{Sn}$ ion by $\mathrm{Cr}$ in the crystal structure results in the coloration of reddish brown. The malayaite crystal has been known to be very stable against heat, which makes it a very good raw material for the main lattice of the pigments used for ceramics. ${ }^{4}$

Because of such merits, the $\mathrm{Cr}_{2} \mathrm{O}_{3}-\mathrm{SnO}_{2}-\mathrm{CaO}-\mathrm{SiO}_{2}$ composition is widely utilized as pigments for ceramic glazes. It is attracting attention in the ceramic industry as the only alternative red type pigment that does not contain cad-

${ }^{\dagger}$ Corresponding author: Hyun-Soo Lee

E-mail : veronica713@hanmail.net

Tel : 82-31-330-6461 Fax : +82-31-330-6457 mium, and can be used at temperatures up to $1300^{\circ} \mathrm{C} .{ }^{1)}$ When the $\mathrm{CaSnSiO}_{5}$ composition was synthesized, malayaite was produced with cassiterite.

The oxidation states of the $\mathrm{Cr}$ ions employed by the produced crystal are mixed, mostly $\mathrm{Cr}$ (III) and Cr (IV), each of which gives different coloration when employed by crystal. ${ }^{1,5)}$ In particular, it has been known that malayaite gives brown coloration and cassiterite a purple type coloration. ${ }^{6,7)}$ When $\mathrm{CrCl}_{3}$ was used as chromophore, it was shown that $\mathrm{Cr}$ ions were employed mostly in the oxidation state of $\mathrm{Cr}(\mathrm{IV}){ }^{8)}$

The present research aimed to obtain the optimal synthetic condition for red coloration, by making $\mathrm{Cr}$ ions employed as chromophore by the malayaite being produced during the synthesis of the $\mathrm{SnO}_{2}-\mathrm{CaO}-\mathrm{SiO}_{2}$ system pigments. In order to maximally promote the employment of $\mathrm{Cr}$ ions by malayaite, changes were made in the firing step and firing time at the temperature malayaite was produced. $\mathrm{CrCl}_{3}$ was used for this purpose as chromophore in place of $\mathrm{Cr}_{2} \mathrm{O}_{3}$. By using $\mathrm{CrCl}_{3}$ as the raw material for coloration, in order to promote the reaction between crystal and chromophore at a low temperature during the synthesis of pigment, it may be possible to lower the synthetic temperature. In addition, a change in the oxidation state of $\mathrm{Cr}$ ion can be anticipated, which may result in the promotion of the employment of $\mathrm{Cr}$ (IV) by malayaite. For this reason an attempt was made to obtain the condition for the synthesis of the pigment which gives an optimal red coloration. 


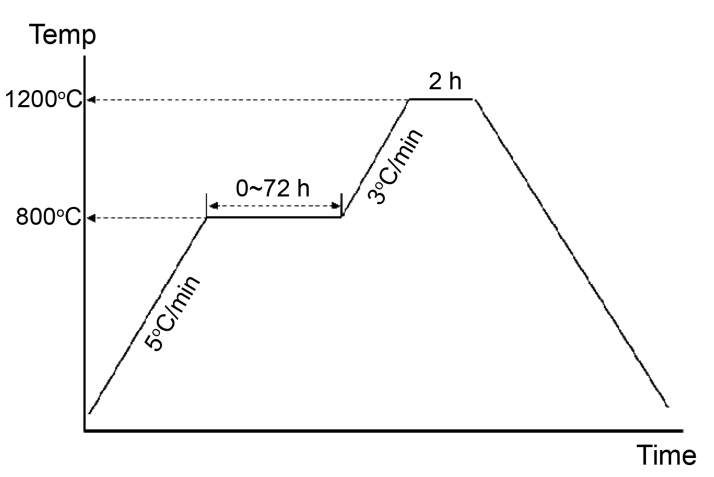

Firing step diagram

(a)

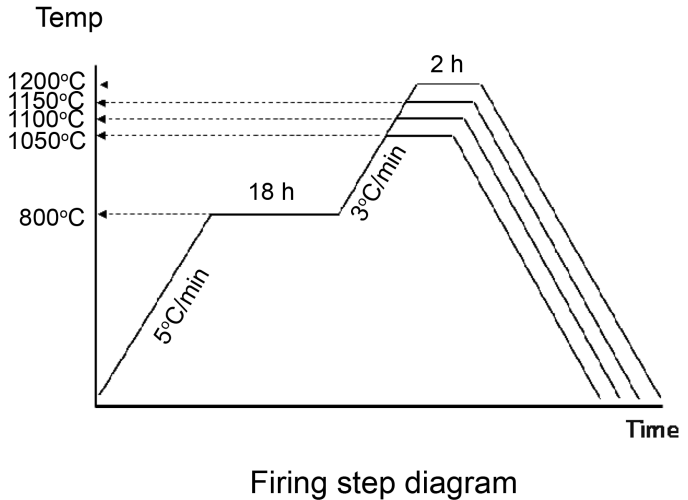

(b)

Fig. 1. Firing step diagrams by time and temperature. (a) First step firing at $800^{\circ} \mathrm{C} / 0 \sim 72 \mathrm{~h}$ and second step at $1200^{\circ} \mathrm{C} / 2 \mathrm{~h},(\mathrm{~b})$ First step firing at $800^{\circ} \mathrm{C} / 18 \mathrm{~h}$ and second step at $1050 \sim 1200^{\circ} \mathrm{C} / 2 \mathrm{~h}$.

\section{Experiments}

\subsection{Starting material}

In order to synthesize the pigments, $\mathrm{CrCl}_{3}$ (Junsei, Extra Pure, Japan), $\mathrm{SnO}_{2}$ (Junsei, Chemical Pure, Japan), and borax (Duksan, Extra Pure, Korea) were selected as starting materials. The basic composition was $\mathrm{CaCr}_{0.02} \mathrm{Sn}_{0.985} \mathrm{SiO}_{5}$, ${ }^{9}$ which had shown the best employment of $\mathrm{Cr}$ ions by the malayaite crystal, with $\mathrm{CrCl}_{3}$ as the coloring material in place of $\mathrm{Cr}_{2} \mathrm{O}_{3}$, and with $4 \%$ of borax added as mineralizer.

The changes in firing condition are shown in Fig. 1. In the case of (a), the condition for the synthesis of pigment was maintenance at $800^{\circ} \mathrm{C}$ for $0 \sim 72 \mathrm{~h}$ as the first firing step and $2 \mathrm{~h}$ at $1200^{\circ} \mathrm{C}$ as the second firing step. In the case of (b), the optimum holding time of the first firing step and the elevated highest temperature of the second firing step were adapted for the synthesis of pigment.

\subsection{Sample analysis}

In order to identify the crystal phase of the synthesized pigment, X-ray diffractometer using a Ni-filtered $\mathrm{CuK} \alpha$ radiation (XRD-7000, Shimadzu, Japan) analysis was carried out with $\mathrm{CaF}_{2}$ added as standard material. The characteristic malayaite phase bands and employment of $\mathrm{Cr}$ ions in malayaite were analyzed by FT-IR (IR Prestige-21, Shimadzu, Japan). The FT-IR spectra were obtained in the reflectance mode using DRS-8000A in the range of $200 \sim 4000 \mathrm{~cm}^{-1}$. Raman spectroscopy (Lambda Solutions, Inc., U.S.A.) analysis was carried out using Vector Raman Probe (RP 532-US). The shape and size of the synthesized pigment particles were observed using SEM (SS-550, Shimadzu, Japan).

The colors of the synthesized pigments and their coloring in lime glaze were analyzed using UV-vis spectroscopy (Shimadzu, UV-2410 PC). The UV-vis spectra were obtained in the range of 200 800 $\mathrm{nm}$ and the result was represented as a spectral reflection curve. The result was also expressed numerically by means of optical color analysis software (P/N 206-67449), using the CIE $L^{*} \mathrm{a}^{*} \mathrm{~b}^{*}$ color system, with $L^{*}$ representing the brightness in the range from black $\left(L^{*}=0\right)$ to white $\left(L^{*}=100\right) . \mathrm{a}^{*}$ is the axis representing the colors in the range from green $\left(-\mathrm{a}^{*}\right)$ to red $\left(+\mathrm{a}^{*}\right)$, while $\mathrm{b}^{*}$ is the axis representing the colors on the range from blue $\left(-b^{*}\right)$ to yellow $\left(+b^{*}\right)$.

For final evaluation of the coloring of the synthesized pigments, experiments were conducted by applying them to the lime glaze. The seger formula for the lime glaze can be referred to below:

\section{$0.3264 \mathrm{KNaO}$$$
0.6588 \mathrm{CaO} \quad 0.4040 \mathrm{Al}_{2} \mathrm{O}_{3} \quad 3.5526 \mathrm{SiO}_{2}
$$$$
0.0148 \mathrm{MgO}
$$

Each of the synthesized pigments was added to lime glaze (6\%) and then fired in an electric furnace by raising the temperature up to $1260^{\circ} \mathrm{C}$ at the rate $3^{\circ} \mathrm{C} / \mathrm{min}$, followed by $40 \mathrm{~min}$ of firing at $1260^{\circ} \mathrm{C}$.

\section{Results and Discussion}

\subsection{Influence of holding time at the first firing step}

Fig. 2 shows the result of the XRD analysis of the samples obtained by varying the holding time from 3 to $72 \mathrm{~h}$ at $800^{\circ} \mathrm{C}$. A comparison between the single peak of the malayaite phase appearing at $33.6^{\circ}$ of the $2 \theta$ value and the peak of the mixed malayaite and cassiterite phases at $33.95^{\circ}$ shows that the relative intensity of the single peak and mixed peak is high as the holding time increases. The reason is that, in the course of synthesis, the formation of malayaite crystal is very much affected by the holding time at the temperature where the crystal began to be formed.

The FT-IR analysis (Fig. 3) of the synthesized pigment showed that the longer holding time resulted in the appearance of a more intensive band of cassiterite. This indicates that the amount of cassiterite increased as the holding time increased, which is in accordance with the XRD analysis. Of the 6 kinds of pigment shown in Fig. 3, the pigment $18 \mathrm{~h}$ shows the smallest band at $345,367 \mathrm{~cm}^{-1}$, which is part of the absorption band of cassiterite. This indicates that the pigment of $18 \mathrm{~h}$ of holding time contains the least amount of cassiterite. The pigment of $18 \mathrm{~h}$ showed bands at $675,705 \mathrm{~cm}^{-1}$, 


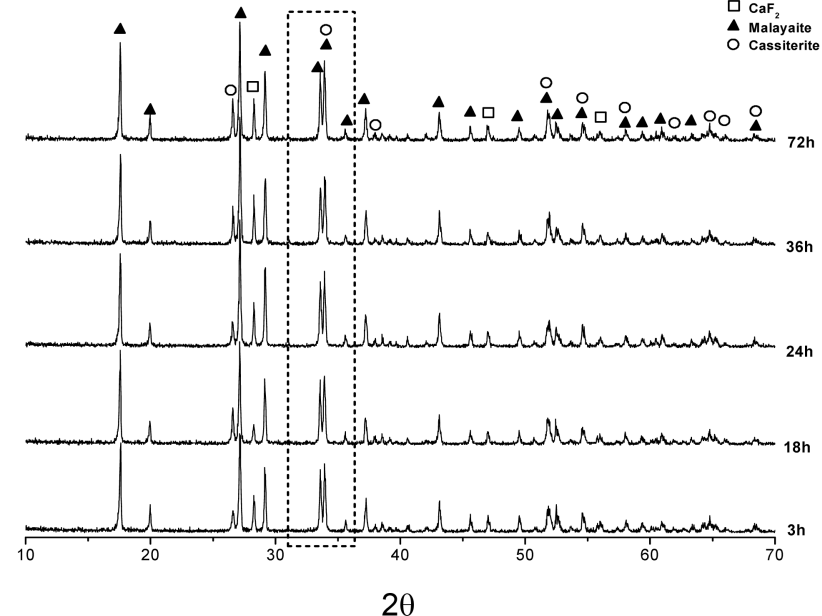

(a)

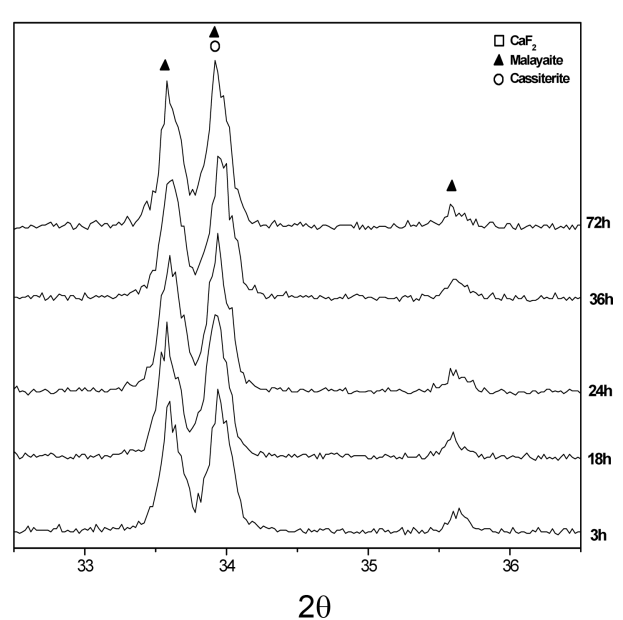

(b)

Fig. 2. (a) XRD patterns of samples of the first fired step at $800^{\circ} \mathrm{C}$ for $3 \sim 72 \mathrm{~h}$ and second step at $1200^{\circ} \mathrm{C} / 2 \mathrm{~h}$, (b) Magnification of interesting peaks $\left(32.5 \sim 36.5^{\circ}\right)$.

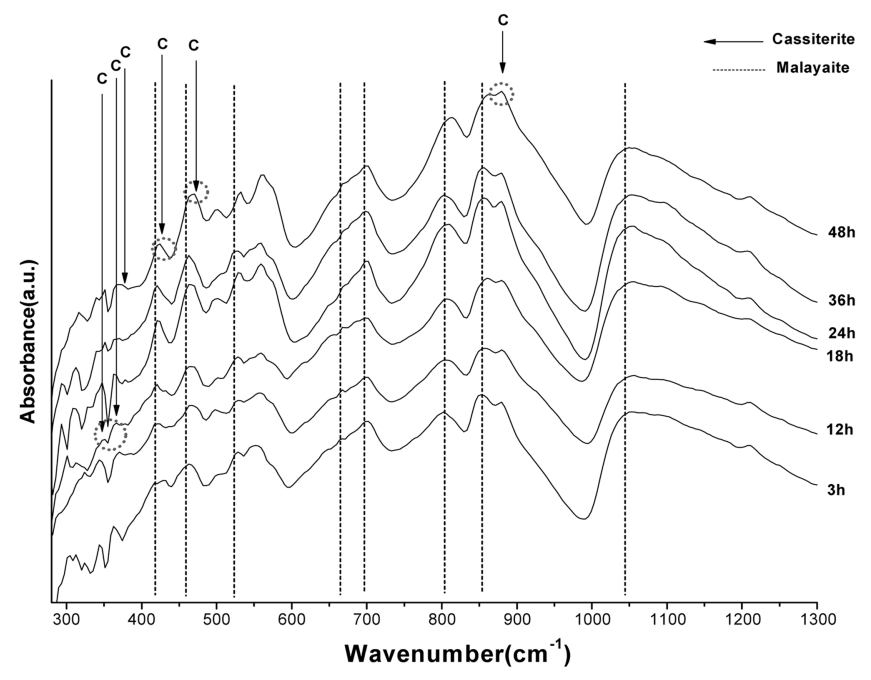

Fig. 3. FT-IR spectra of samples fired in the first step at $800^{\circ}$ for $3 \sim 48 \mathrm{~h}$ and second step at $1200^{\circ} \mathrm{C} / 2 \mathrm{~h}$.

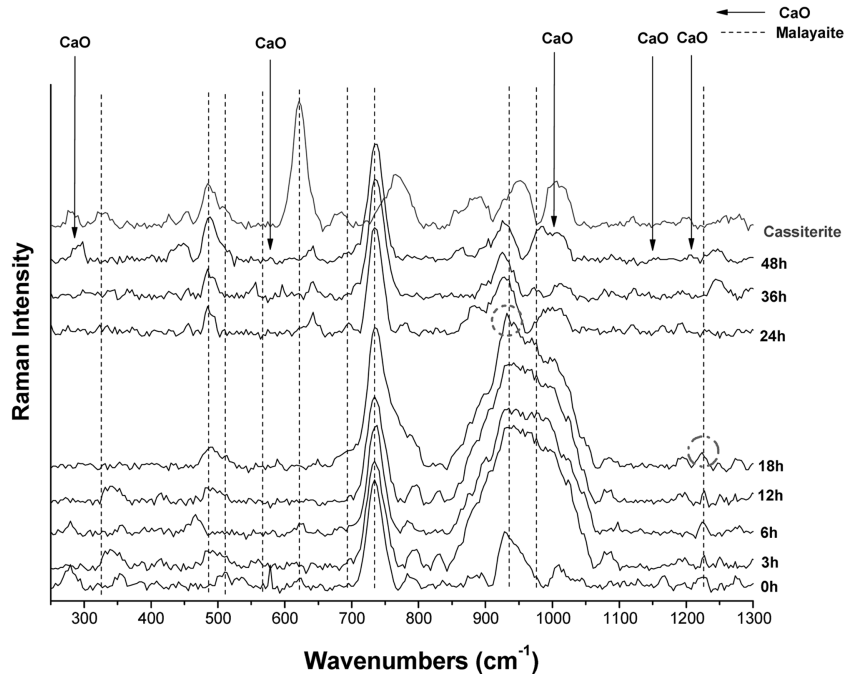

Fig. 4. Raman Spectra of Samples fired in the first step at $800^{\circ} \mathrm{C}$ for $3 \sim 48 \mathrm{~h}$ and second step at $1200^{\circ} \mathrm{C} / 2 \mathrm{~h}$.
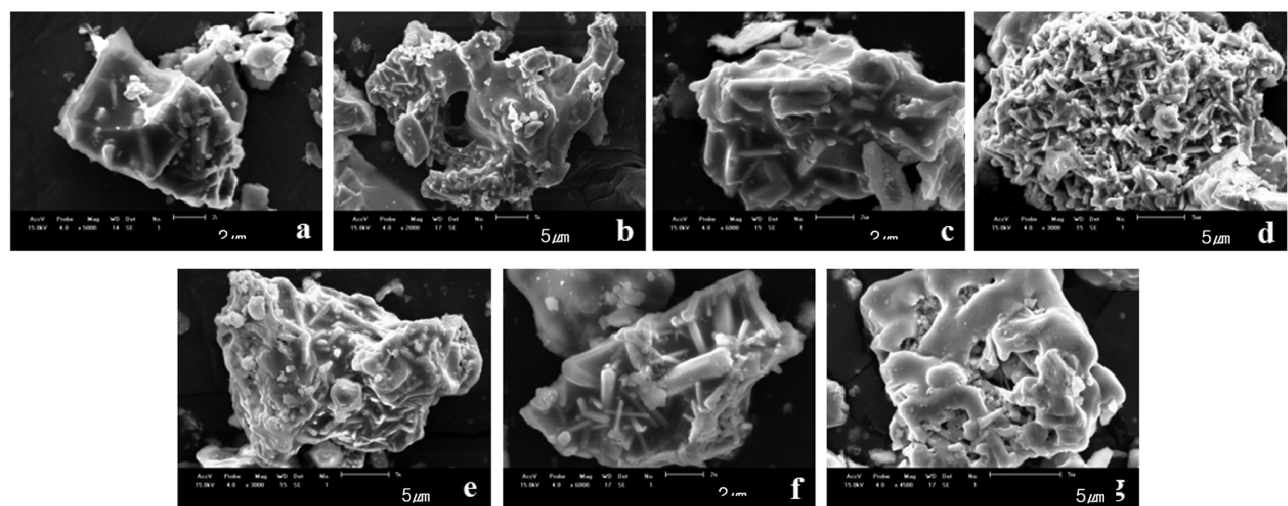

Fig. 5. SEM Analysis of Samples fired in the first step at $800^{\circ} / 3 \sim 72 \mathrm{~h}$ and second step at $1200^{\circ} / 2 \mathrm{~h}$. (a) $3 \mathrm{~h}$, (b) $6 \mathrm{~h}$, (c) $12 \mathrm{~h}$, (d) $18 \mathrm{~h}$, (e) $24 \mathrm{~h}$, (f) $36 \mathrm{~h}$, and (g) $72 \mathrm{~h}$.

indicating that the $\mathrm{Cr}$ (IV) ion was employed by the malayaite crystal. ${ }^{10)}$ That means malayaite employed more of the $\mathrm{Cr}$ (IV) ion than cassiterite, which is the main factor of red coloring.

The reason for such a phenomenon is clearly explained by the Raman spectra analysis shown in Fig. 4. As for the first 


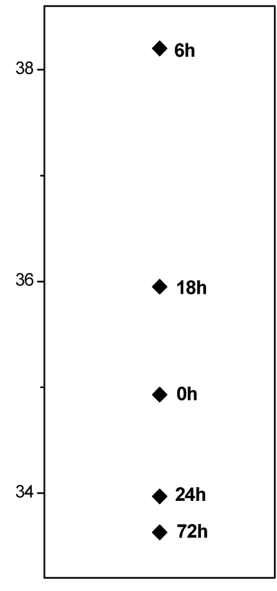

$\mathbf{L}^{*}$

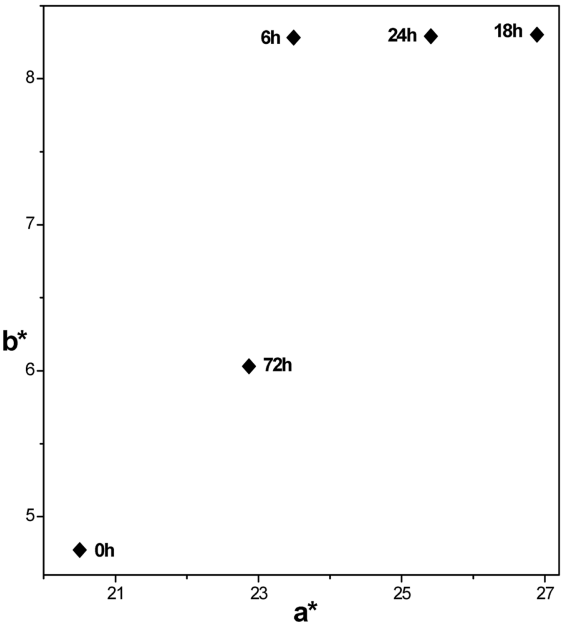

Fig. 6. CIE $L^{*} \mathrm{a}^{*} \mathrm{~b}^{*}$ colorimetric parameters of glaze application samples fired in the first step at $800^{\circ} \mathrm{C} / 3 \sim 72 \mathrm{~h}$ and second step at $1200^{\circ} \mathrm{C}$.

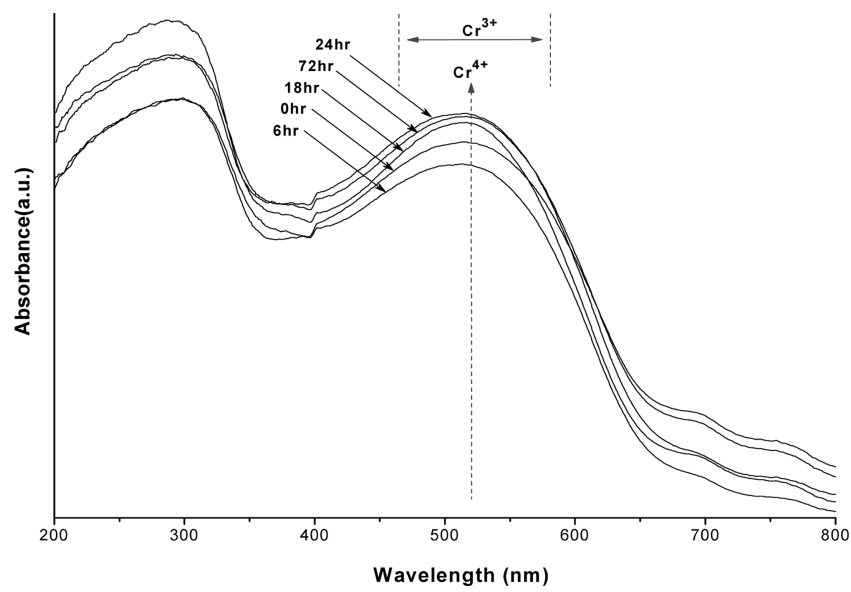

Fig. 7. UV-VIS spectra of glaze application samples fired at the first step at $800^{\circ} \mathrm{C} / 3 \sim 72 \mathrm{~h}$ and second step at $1200^{\circ} \mathrm{C}$.

$3 \sim 18 \mathrm{~h}$ of holding time the intensity of the characteristic peak of malayaite increased as the holding time increased, the pigment $18 \mathrm{~h}$ showed the most intense peak at 940, $1212 \mathrm{~cm}^{-1}{ }^{11)}$ But when the holding time was increased to $24 \sim 48 \mathrm{~h}$, the intensity of the peak of malayaite decreased; while a new peak of $\mathrm{CaO}$ appeared, accompanied by an increase in the intensity of the peak of cassiterite. This indicates that when the holding time is longer than $24 \mathrm{~h}$, part of the malayaite phase is decomposed, resulting in the increase in the amount of cassiterite and the appearance of the peak of $\mathrm{CaO}$.

The observation by SEM of the pigments in Fig. 5 reveals that the bar type means the malayaite phase existed in all the samples, especially pigment (d), which underwent $18 \mathrm{~h}$ of holding time and contained the largest amount of the malayaite phase produced. As the holding time was extended up to $72 \mathrm{~h}$, there was severe coagulation of particles, with the appearance of a glass phase formed by the reaction between $\mathrm{CaO}$ and $\mathrm{SiO}_{2}$ from the decomposition of malayaite.

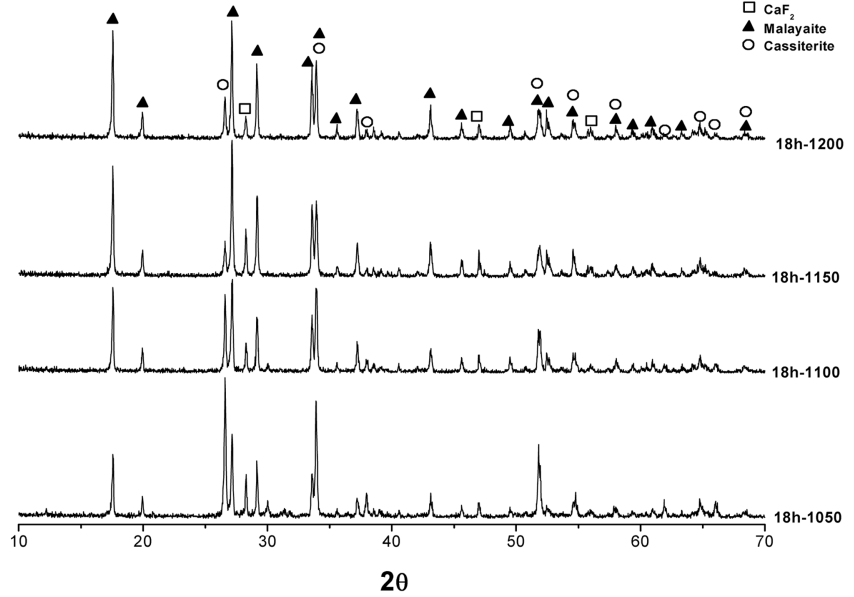

Fig. 8. XRD patterns of samples fired in first step at $800^{\circ} \mathrm{C} /$ $18 \mathrm{~h}$ and second step at $1200 \sim 1050^{\circ} \mathrm{C} / 2 \mathrm{~h}$.

The changes in color as the result of applying $6 \mathrm{wt} \%$ of the synthesized pigments to lime glaze were expressed as CIE $L^{*} \mathrm{a}^{*} \mathrm{~b}^{*}$ values. The pigment synthesized without intervening the holding time, the pigment $0 \mathrm{~h}$, showed the lowest $\mathrm{a}^{*}$ and $\mathrm{b}^{*}$ values, but the $\mathrm{a}^{*}$ value became larger as the holding time increased. The $\mathrm{a}^{*}$ value was largest when the intervening holding time was $18 \mathrm{~h}$, resulting in the best red color. When the holding time was increased over $18 \mathrm{~h}$, however, the $\mathrm{a}^{*}$ value became rather low; whereas when the holding time was $72 \mathrm{~h}$, there was a drastic decrease in both the $\mathrm{a}^{*}$ and $\mathrm{b}^{*}$ values. This is due to the influence of the $\mathrm{CaO}, \mathrm{SiO}_{2}$, and $\mathrm{SnO}_{2}$ (cassiterite) produced as the result of the decomposition of malayaite.

Both Cr (III) and Cr (IV) ions are employed by the malayaite crystal, and $\mathrm{Cr}$ (IV) has been reported to exert an influence on the red coloration in glaze. In order to determine the oxidation state of the $\mathrm{Cr}$ ions employed by the malayaite crystal of the synthesized pigments, UV-vis analysis was carried out on the pigments applied to glaze. The result is shown in Fig. 7.

The absorption bands reflect the oxidation state of $\mathrm{Cr}$ ions. The absorption band at $520 \mathrm{~nm}$ originated from the employed $\mathrm{Cr}$ (IV) ions in the malayaite crystal is explained by diagram of Tanabe-Sugano as ${ }^{3} \mathrm{~A}_{2 \mathrm{~g}}(\mathrm{~F}) \rightarrow{ }^{3} \mathrm{~T}_{1 \mathrm{~g}}(\mathrm{~F}){ }^{7,12)}$ The relative strong band of sample $18 \mathrm{~h}$ is shown at $520 \mathrm{~nm}$. This result indicates that the majority of the employed ions are $\mathrm{Cr}$ (IV). Whereas the pigments of the $0 \mathrm{~h}$ and the 24 and $72 \mathrm{~h}$ of holding time showed an increase in the intensity of the band at $600 \mathrm{~nm}$, indicating increased employment of $\mathrm{Cr}$ (III). ${ }^{7,12)}$ As shown in Fig. 6, the pigment $18 \mathrm{~h}$ has the largest $\mathrm{a}^{*}$ value, since it has the largest amount of employed $\mathrm{Cr}$ (IV), which exerts the greatest effect on the color of glaze.

The observation by SEM revealed coagulation in all the pigments, as shown in Fig. 5, and thus an attempt was made to lower the synthetic temperature.

3.2. Influence of temperature at the second fring step The new firing condition was $18 \mathrm{~h}$ at $800^{\circ} \mathrm{C}$, as in the case 


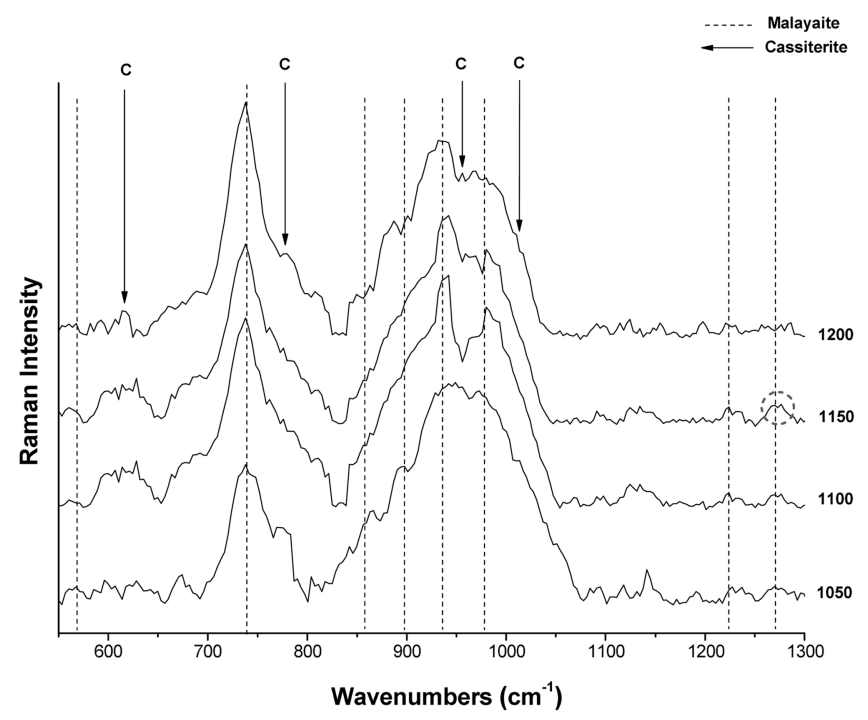

Fig. 9. Raman spectra of samples fired in the first step at $800^{\circ} \mathrm{C} / 18 \mathrm{~h}$ and second step at $1200 \sim 1050^{\circ} \mathrm{C} / 2 \mathrm{~h}$.

of (b) in Fig. 1, followed by $2 \mathrm{~h}$ at the highest temperature that was lowered in a stepwise manner from $1150^{\circ} \mathrm{C}$ to $1100^{\circ} \mathrm{C}$ and $1050^{\circ} \mathrm{C}$. The results of the XRD analysis of the synthesized pigments are shown in Fig. 8 . The result shows that the main peak of the pigments synthesized at the firing temperature of $1050 \sim 1100^{\circ} \mathrm{C}$ corresponded to cassiterite, indicating that malayaite had not been sufficiently produced. Whereas the main peak of the pigment synthesized at $1150^{\circ} \mathrm{C}$ corresponded to malayaite. This is almost the same result as in the case where pigment was synthesized at $1200^{\circ} \mathrm{C}$, indicating that the synthetic temperature could be lowered according to the changes in the length of the intervening holding time.

Fig. 9 shows the result of the Raman spectroscopy analysis, carried out to compare the crystal phases produced in the pigments synthesized at $1150^{\circ} \mathrm{C}$ and $1200^{\circ} \mathrm{C}$. The result shows that the peaks of cassiterite, very weak peaks appearing at $616,778,956$, and $1013 \mathrm{~cm}^{-1}$, are relatively more intensive in the case of the pigment synthesized at $1200^{\circ} \mathrm{C}$ than in the case of the pigment synthesized at $1150^{\circ} \mathrm{C}$, whereas the peak of malayaite was most intensive in the case of the pigment synthesized at $1150^{\circ} \mathrm{C}$. Thus the optimum synthetic temperature might be $1150^{\circ} \mathrm{C}$.

Fig. 10 shows the result of the overvation by SEM of the

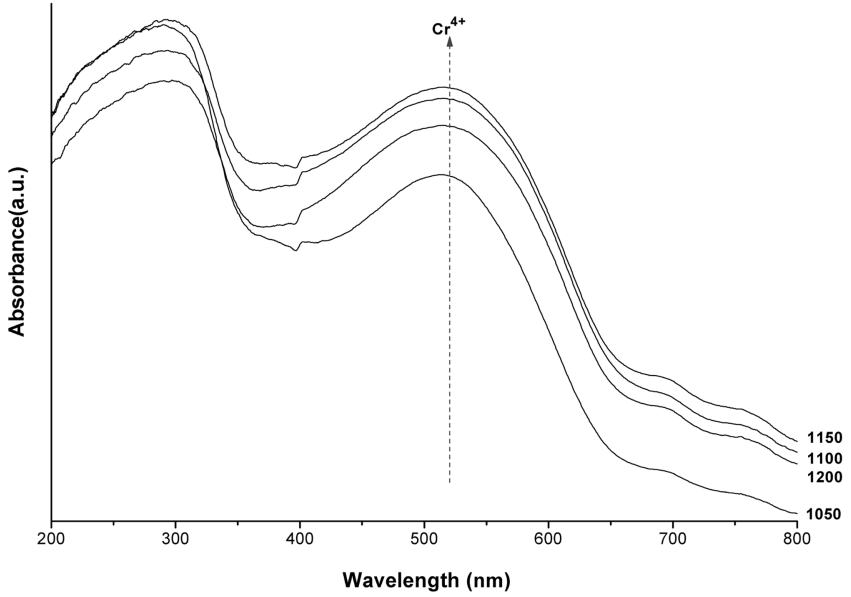

Fig. 11. UV-VIS spectra of samples fired at the first step at $800^{\circ} \mathrm{C}$ for $18 \mathrm{~h}$ and second step at $1200 \sim 1050^{\circ} \mathrm{C} / 2 \mathrm{~h}$

pigments synthesized at $1050 \sim 1200^{\circ} \mathrm{C}$. The result confirmed that a larger amount of the particles of the malayaite crystal were produced in the pigments synthesized at $1150^{\circ} \mathrm{C}$ and $1200^{\circ} \mathrm{C}$ than in the pigment synthesized at $1050^{\circ} \mathrm{C}$, whereas the pigment synthesized at $1200^{\circ} \mathrm{C}$ showed more agglomerative than the pigment synthesized at $1150^{\circ} \mathrm{C}$. Thus the optimum synthetic temperature of the pigment was expected at $1150^{\circ} \mathrm{C}$.

Fig. 11 shows the result of the UV analysis of the fired specimens that contains $6 \mathrm{wt} \%$ of pigments added to lime glaze. The pigment synthesized at $1150^{\circ} \mathrm{C}$ showed the most intensive absorbtion band at $520 \mathrm{~nm},{ }^{7,12)}$ with the most vivid and richest coloration. Thus the optimal firing condition for the synthesis of pink pigment was shown to be $18 \mathrm{~h}$ of holding time at $800^{\circ} \mathrm{C}$, followed by $2 \mathrm{~h}$ at $1150^{\circ} \mathrm{C}$.

\section{Conclusions}

Pink pigment was synthesized using the composition $\mathrm{CaCr}_{0.02} \mathrm{Sn}_{0.985} \mathrm{SiO}_{5}$ with $\mathrm{CrCl}_{3}$ as the substitute for $\mathrm{Cr}_{2} \mathrm{O}_{3}$ and $4 \mathrm{wt} \%$ of borax as mineralizer. In the case of synthesizing sphene-pink pigments at $1200^{\circ} \mathrm{C}$, cassiterite and $\mathrm{CaO}$ phases appeared due to decomposition of malayaite over a holding time of $24 \mathrm{~h}$ at $800^{\circ} \mathrm{C}$. The optimum condition for synthesis of sphene-pink pigments was a holding time of $18 \mathrm{~h}$ at $800^{\circ} \mathrm{C}$ and malayaite was produced by maintaining
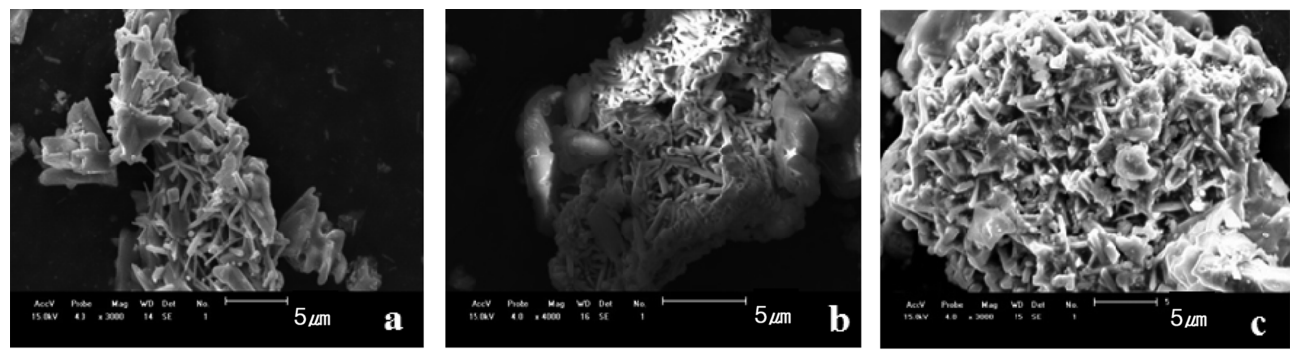

Fig. 10. SEM analysis of samples fired at the first step at $800^{\circ} / 18 \mathrm{~h}$ and second step at $1050 \sim 1200^{\circ} \mathrm{C} / 2 \mathrm{~h}$, (a) 1050 , (b) 1150 , and (c) $1200^{\circ} \mathrm{C}$. 
$2 \mathrm{~h}$ at $1150^{\circ} \mathrm{C}$. At the optimum condition, employment of $\mathrm{Cr}$ (IV) which exerts a great effect on the red coloration of pigments gave the best chromaticity ( $\left.\mathrm{a}^{*}\right)$ value of pigment in glaze.

\section{Acknowledgment}

This work was supported by a Korea Science and Engineering Foundation (KOSEF) grant funded by the Korean government (MOST) (No. ROA-2006-000-10442-0).

\section{REFERENCES}

1. P. E. Lopez, C. G. Monzonis, and J. A. Navarro, "Cr-SnO ${ }_{2}$ CaO-SiO ${ }_{2}$-Based Ceramic Pigments," Am. Ceram. Soc. Bull., 63 [12] 1492-94 (1984).

2. E. Cordoncillo, F. de Rio, J. Carda, M. Llusar, and P. Escribano,"Influence of Some Mineralizers in the Synthesis of Sphene-Pink Pigments," J. Eur. Ceram. Soc., 18 1115-20 (1998).

3. V. Harisanova, R. S. Pavlovb, I. T. Marinovab, V. Kozhukharova, J. and B. Cardab, "Influence of Crystallinity on Chromatic Parameters of Enamels Coloured with Malayaite Pink Pigments," J. Eur. Ceram. Soc., 23 429-35 (2003).

4. E. López-Navarrete, A. Caballero, V. M. Orera, F. J. Lázaro, and M. Ocaná, "Oxidation State and Localization of Chromium Ions in Cr-doped Cassiterite and Cr-doped Malayaite," J. Acta Mat., 51 [8] 2371-81 (2003).

5. B. Julián, H. Beltrán, E. Cordoncillo, P. Escribano, J. V.
Folgado, M. Vallet-Regí, and R. P. del Real, "A Study of the Method of Synthesis and Chromatic Properties of the Cr$\mathrm{SnO}_{2}$ Pigment," Eur. J. Inorg. Chem., 10 2694-700 (2002).

6. E. López-Navarrete and M. Ocaña, "A Simple Procedure for the Preparation of Cr-doped Tin Sphene Pigments in the Absence of Fluxes," J. Eur. Ceram. Soc., 22 [3] 353-59 (2002).

7. G. Monrós, H. Pinto, J. Badenes, M. Llusar, and M. A. Tena, "Chromium (IV) Stabilization in New Ceramic Matrices by Coprecipitation Method: Application as Ceramic Pigments," Z. Anorg. Allg. Chem., 631 [11] 2131-35 (2005).

8. H. S. Lee and B. H. Lee, "Influence of $\mathrm{CrCl}_{3}$ in Sphene-Pink Pigments," J . Kor. Ceram. Soc., 45 [5] 268-75 (2008).

9. H. S. Lee and B. H. Lee, "Coloring Effect of Malayaite Formation and Synthesis Sphene-Pink Pigment," J. Kor. Ceram. Soc., 45 [3] 172-78 (2008).

10. F. J. Berry, N. Costanatini, and L. E. Smart, "Synthesis of Chromium-containing from Pigment Chromium Recovered from Leather Waste," J. Waste Management, 22 [7] 761-72 (2002).

11. A. M. Heyns and P. M. Harden, "Evidence for the Existence of $\mathrm{Cr}$ (IV) in Chromium-doped Malayaite $\mathrm{Cr}^{4+}$ : $\mathrm{CaSnOSiO}_{4}$ : a Resonance Raman Study," J. Physics and Chemistry of Solids, 60 277-84 (1999).

12. A. Doménech, F. J. Torres, E. Ruiz de Sola, and J. Alarcón, "Electrochemical Detection of High Oxidation States of Chromium (IV and V) in Chromium-Doped Cassiterite and Tin-Sphene Ceramic Pigmenting Systems," Eur. J. Inorg. Chem., 3 638-48 (2006). 